\title{
PEMANFAATAN KOTORAN SAPI MENJADI PUPUK ORGANIK DI DESA MAS-MAS KECAMATAN BATUKLIANG UTARA KABUPATEN LOMBOK TENGAH
}

\author{
UTILIZATION OF COW WASH TO BE ORGANIC FERTILIZER IN MAS-MAS \\ VILLAGE, BATUKLIANG UTARA DISTRICT, CENTRAL LOMBOK DISTRICT \\ Ayu Nirmaniar Fadliani ${ }^{1}$, Dini Dwi Lestari ${ }^{2}$, Mia Siti Fatimah ${ }^{3}$, I Gde Mertha ${ }^{4}{ }^{*}$. \\ ${ }^{1}$ Fakultas Pertanian Universitas Mataram \\ ${ }^{2}$ Fakultas Teknik Universitas Mataram \\ ${ }^{3}$ Fakultas Teknik dan Pangan Universitas Mataram \\ ${ }^{4}$ Fakultas Keguruan dan IImu Pendidikan \\ *Email: igdemertha@yahoo.com
}

\begin{abstract}
ABSTRAK. Pengolahan kotoran sapi menjadi pupuk organik bertujuan untuk menghasilkan suatu produk olahan yang memiliki nilai tambah dibandingkan dengan sebelum dilakukan pengolahan. Pengolahan kotoran sapi ini dilatarbelakangi dengan kurangnya kesadaran masyarakat Desa Mas-Mas tentang pengolahan kotoran sapi. Alternatif solusi yang dapat dilakukan untuk mengatasi kendala tersebut dengan mengadakan penyuluhan pemanfaatan limbah kotoran sapi. Tujuan dari program ini adalah mampu memanfaatkan limbah kotoran sapi sehingga dapat digunakan sebagai pupuk organik dan meningkatkan pendapat masyarakat Desa Mas-Mas. Metode yang digunakan adalah melaui proses identifikasi area sasaran yakni Desa Mas-Mas, kemudian dilanjutkan dengan observasi dan wawancara langsung antara kami dari KKN Universitas Mataram dengan warga. Setelah itu kami kemudian melakukan sosialisasi kepada warga, pengaturan jadwal penyuluhan, kemudian melakukan penyuluhan dan praktek langsung tentang cara membuat kotoran sapi menjadi pupuk organik. Hasil dari program pemberdayaan masyarakat ini adalah ibu rumah tangga Desa Mas-Mas dapat mengembangkan program pembuatan pupuk organik dari limbah kotoran sapi sebagai upaya berkelanjutan dari program pengembangan pertanian.
\end{abstract}

Kata kunci: Desa Mas-Mas, kotoran sapi, pupuk organik

\begin{abstract}
Processing cow manure into organic fertilizer aims to produce a processed product that has added value compared to before processing. The processing of cow manure is motivated by a lack of awareness of the Mas-Mas Village community about processing cow dung. Alternative solutions that can be done to overcome these obstacles by holding information on the utilization of cow manure. The aim of this program is to be able to utilize cow manure so that it can be used as organic fertilizer and increase the income of the Mas- Mas Village community. The method used is through the process of identifying the target area namely Mas-Mas Village, then followed by observation and direct interviews between us from the University of Mataram KKN with residents. After that, we then disseminated information to residents, arranged counseling schedules, then conducted counseling and direct practice on how to make cow manure into organic fertilizer. The result of this community empowerment program is that the village housewives Mas-Mas can develop a program to make organic fertilizer from cow manure as a continuous effort from an agricultural development program.
\end{abstract}

Keyword: Mas-Mas Village, cow manure, organic fertilizer 


\section{PENDAHULUAN}

Desa Mas-Mas merupakan satu desa yang ada di kecamatan Batukliang Utara abupaten Lombok Tengah Provinsi Nusa Tenggara Barat dengan luas wilayah $2.23 \mathrm{~km}^{2}$. Desa Mas-Mas terdiri dari sebelas dusun dengan jumlah penduduk sebanyak 4310 jiwa. Desa Mas-Mas merupakan salah satu desa wisata yang dikelilingi oleh area pertanian dan pertenakan yang mana sebagian masyarakat berprofesi sebagai petani dan peternak dan mayoritas penduduknya mengandalkan sektor pertanian dan peternakan sebagai mata pencaharian pokok.

Pembangunan pertanian merupakan salah satu aspek penting dalam pembangunan desa, yang mana akan berdampak pada pertumbuhan ekonomi masyarakat desa dan mengurangi angka kemiskinan yang ada di desa. Sehingga peranan petani sangat menentukan keberhasilan pembangunan tersebut. Tantangan utama yang dihadapi dewasa ini adalah bagaimana menghasilkan pertanian yang berdaya saing tinggi baik dalam aspek kuantitas, kualitas, ragam produk, kontinuitas, pelayanan maupun harga, sehingga dapat memenuhi tuntutan pasar domestik maupun pasar global. Menjawab tantangan Pertanian tersebut di atas, pemerintah memberikan perhatian terhadap sub sektor pertanian yaitu dengan menempatkan peternakan sebagai basis peningkatan perekonomian rakyat. Seiring dengan peningkatan jumlah penduduk, peningkatan perekonomian memacu pertumbuhan para petani pertanian skala rumah tangga di berbagai daerah di Indonesia. Kondisi ini akan berakibat terhadap peningkatan dalam pemenuhan gizi di Indonesia yang secara tidak langsung akan meningkatkan jumlah faices yang perlu dipikirkan penanganannya.

Seiring dengan perkembangan zaman dalam melakukan kegiatan bertani dan berternak, masyarakat di Desa Mas-Mas pada saat ini telah menggunakan alat-alat ataupun bahan kimia untuk memudahkan kegiatan dan untuk meningkatkan penghasilan dalam bertani dan beternak. Hal ini terlihat dari hasil yang di dapatkan memiliki kualitas, kuantitas, dan berdaya saing tinggi. Simanungkalit dkk (2006) dalam bukunya menerangkan bahwa penggunaan pupuk an-organik secara besar-besaran terjadi justru setelah revolusi hijau berlangsung, hal tersebut dikarenakan penggunaan pupuk kimia/an- organik dirasa lebih praktis dari segi pengaplikasiannya pada tanaman, jumlahnya takarannya jauh lebih sedikit dari pupuk organik serta relatif lebih murah karena saat itu harga pupuk disubsidi oleh pemerintah. Akan tetapi dalam kehidupan di pedesaan banyak masyarakat Mas-Mas belum menyadari imbas penggunaan jangka panjang dari pupuk kimia anorganik justru berbahaya karena penggunaan pupuk an-organik tunggal secara terus menerus dalam jangka panjang akan membuat tanah menjadi keras karena residu sulfat dan dan kandungan karbonat yang terkandung dalam pupuk dan tanah bereaksi terhadap kalsium tanah yang menyebabkan sulitnya pengolahan tanah (Roidah, 2013).

Pupuk organik adalah bahan organik yang umumnya berasal dari tumbuhan atau hewan, ditambahkan ke dalam tanah secara spesifik sebagai sumber hara, pada umumnya mengandung nitrogen $(\mathrm{N})$ yang berasal dari tumbuhan dan hewan (Susanto, 2002).Peraturan Menteri Pertanian No. 28/Permentan/SR.130/5/2009 menyatakan bahwa pupuk organik adalah pupuk yang berasal dari sisa tanaman dan kotoran hewan yang telah melalui proses rekayasa, berbentuk padat atau cair dan dapat diperkaya dengan bahan mineral lami atau mikroba yang bermanfaat memperkaya hara, bahan organik tanah, memperbaiki sifat fisik, kimia, dan biologi tanah (Firmansyah, 2011). Pupuk organik mempunyai kandungan unsur, terutama nitrogen $(N)$, phosphor $(P)$, dan kalium $(K)$ sangat sedikit, tetapi mempunyai peranan lain yang sangat berpengaruh terhadap pertumbuhan, perkembangan dan kesehatan tanaman (Suriawiria, 2003). Peluang penggunaan pupuk organik pada masa mendatang cukup besar. Hal ini dikarenakan oleh berbagai hal, antara lain: harga pupuk 
kimia semakin mahal akibat pengurangan subsisi pupuk oleh pemerintah, tingkat kesuburan tanah semakin menurun, kesadaran petani terhadap bahaya residu pupuk kimia semakin tinggi dan adanya tren pertanian organik yang semakin tinggi (Musnamar, 2003). Tidak dapat dipungkiri bahwa pupuk organic mampu meningkatkan produksi pertanian, tetapi juga dapat menimbulkan dampak negatif bila diterapkan secara berlebihan dan terus menerus, apalagi bila bahan bakunya mengandung bahan-bahan berbahaya seperti logam berat dan asamasam organik (Setyorini, 2005). Dengan berkembangnya pertanian dan pangan organik beberapa dekade terakhir ini maka pemanfaatan pupuk organik dalam budidaya pertanian organik terbuka lebar. Hingga tahun 2007 peningkatan permintaan pasar berbagai produk pertanian organik lokal di Indonesia mencapai 60\% (Hermawan dan Astuti, 2007).

Namun, berdasarkan observasi dan wawancara langsung antara kami Mahasiswa KKN (Kuliah Kerja Nyata) Universitas Mataram dengan warga desa Mas-Mas, Batukliang Utara didapatkan fakta bahwa rata-rata petani di desa tersebut masih menggunakan pupuk kimia an-organik untuk lahan dan tanaman dalam areal pertanian mereka, sedangkan kami melihat bahwa rata-rata mereka memelihara ternak salah satunya seperti sapi, maka kami tergerak untuk melakukan penyuluhan dan praktek langsung tentang cara membuat pupuk organik dengan memanfaatkan kotoran sapi kepada para petani di desa tersebut. Pemilihan kotoran sapi selain karena hewan tersebut menjadi salah satu ternak yang banyak dipelihara warga Mas-Mas tetapi juga didasarkan pada beberapa penelitian dalam dunia pertanian yang menunjukkan bahwa penggunaan pupuk kotoran sapi sebanyak $20 \mathrm{t}$ ha-1 mampu memberikan hasil biji 1,21 tha-1 pada tanaman kedelai dan penambahan pupuk kandang dengan dosis 30 tha-1 mampu memberikan hasil padi gogo 5,9 $\mathrm{t}$ ha-1 (Atmojo, 2003). Karenanya kami dari KKN Universitas Mataram sangat berharap kegiatan ini memberikan dampak positif bagi warga sehingga dapat membantu meningkatkan taraf hidup mereka secara ekonomi.

\section{METODE PELAKSANAAN Waktu dan Tempat}

Kegiatan dilakukan Minggu, 17 Februari 2019 di Desa Mas-Mas, Kecamatan Batukliang Utara, Kabupaten Lombok Tengah

\section{Alat dan Bahan}

Alat yang digunakan dalan program ini adalah ember plastik, cangkul, skop, pengaduk. Bahan yang digunakan adalah kotoran sapi, air, dan tanah gembur.

\section{Prosedur Kerja Pembuatan Pupuk Organik}

Prosedur kerja pembuatan pupuk organik adalah : 1) Mempersiapkan alat dan bahan, 2) Mengumpulkan kotoran sapi, 3) Mengumpulkan tanah gembur, 4) Mencampur dan mengaduk semua bahan , 5) Mengemas dalam wadah baru.

\section{Bentuk Kegiatan}

Bentuk kegiatan secara keseluruhan ini adalah 1) Persiapan program, 2) Sosialisasi tentang pembuatan pupuk organik, 3) Pelatihan Pembuatan pupuk organik, 4) Pengaplikasian hasil pupuk organik, 5) Monitoring dan evaluasi 
Metode Pengumpulan dan Analisis Data Metode pengumpulan data pada program ini adalah dengan identifikasi area sasaran dan observasi dengan warga setempat.

\section{HASIL DAN PEMBAHASAN}

Kotoran ternak tetap ada setiap harinya sehingga menimbulkan banyak masalah diantaranya lingkungan yang kotor dan bau yang tidak sedap. Hal ini menuntut perlunya dilakukan pengolahan kotoran ternak menjadi pupuk organik agar terciptanya lingkungan yang bersih dan juga dapat menghemat pengeluaran keluarga. Hasil yang dicapai dalam kegiatan ini adalah sadarnya masyarakat akan pentingnya penggunaan pupuk organik bagi tanaman serta manfaatnya dalam menjaga mineral tanah agar tetap subur sehingga dalam jangka panjang dapat tetap memberikan hasil panen yang melimpah. Melalui kegiatan ini warga juga menjadi lebih mengerti mengenai dampak buruk penggunaan jangka panjang dari pupuk kimia an-organik. Satu hal yang paling penting adalah masyarakat mengetahui cara membuat pupuk organic secara mandiri menggunakan bahan dasar yang ada disekitar mereka, dalam hal ini kotoran sapi dan kotoran hewan lain pada umumnya. Penyuluhan ini juga membuat warga antusias dan tertarik untuk mulai menggunakan pupuk kandang seperti pupuk kotoran sapi untuk menyuburkan tumbuhan dan tanah pada areal pertanian mereka.

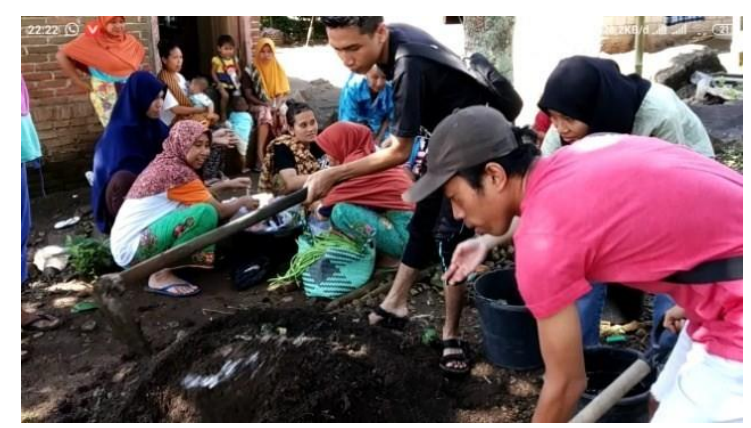

Gambar 1. Pembuatan pupuk kandang.

\section{KESIMPULAN}

Pupuk organik adalah pupuk yang berasal dari sisa tanaman dan kotoran hewan yang telah melalui proses rekayasa, berbentuk padat atau cair dan dapat diperkaya dengan bahan mineral lami atau mikroba yang bermanfaat memperkaya hara, bahan organik tanah, memperbaiki sifat fisik, kimia, dan biologi tanah. Setelah mengetahui manfaat penggunaan pupuk organik dan cara mengolahnya masyarakan desa Mas-Mas yang berprofesi sebagai petani diharapkan dapat menghindari penggunaan pestisida atau pupuk kimia an-organik sehingga mengurangi resiko keracunan zat tersebut dan mengurangi dampak kerusakan tanah jangka panjang. Penggunaan pupuk organik buatan sendiri juga dianjurkan guna menghemat biaya operasional dan petani lebih banyak memperoleh laba bersih dari hasil pertanian mereka sehingga berdasarkan hal tersebut pengelolaan limbah peternakan menjadi pupuk organik mempunyai prospek yang baik sekali untuk dikembangkan kedepannya.

\section{DAFTAR PUSTAKA}




\section{Jurnal Warta Desa}

www.jwd.unram.ac.id

Vol. 1 NO. 1 April 2019

Atmojo. S. Wongso., (2003). Peranan Bahan Organik Terhadap Kesuburan Tanah dan Upaya Pengelolaannya. Makalah (disampaikan pada pidatopengukuhan guru besar Fakultas Pertanian UNS). Surakarta: Sebelas Maret University Press

Badan Pusat Statisik Provinsi Nusa Tenggara Barat. 2012. Nusa Tenggara Barat Dalam Angka 2014. Lombok Tengah.

Firmansyah. M. Anang., (2011). Peraturan tentang Pupuk,Klasifikasi Pupuk Alternatif dan Peranan Pupuk Organik dalam peningkatan produksi pertanian. Makalah (disampaikan pada apresiasi pengembangan pupuk organik, di dinas Pertanian). Palangkaraya.

Hermawan, E. dan Astuti, F. D., 2007, Di Balik Label Organik. Agro Observer, November, 18-20.

Musnamar, E. I., 2003, Pupuk Organik Padat: Pembuatan dan Aplikasinya, Jakarta, Penebar Swadaya.

Roidah. (2013). Manfaat Penggunaan Pupuk Organik Untuk Kesuburan Tanah. Jurnal universitas Tulung Agung BONOROWO. Vol I (1).

Setyorini, D., 2005, Pupuk Organik Tingkatkan Produksi Tanaman. Warta Penelitian dan Pengembanagn Pertanian, 27, 1315.

Simanungkalit.R.D.M, dkk (2006). Pupuk Organik dan Pupuk Hayati/Organic Fertilizer dan Biofertilizer. Bogor: LITBANG,DEPTAN

Suriawiria, U., 2002, Pupuk Organik Kompos dari Sampah. Bandung: Humaniora, 53.

Susanto, R.2002. Penerapan Pertanian Organik. 